\title{
Request for professional medical aid on board ocean-going ships in the Republic of Croatia
}

\author{
Rosanda Mulić ${ }^{1}$, Dean Sumić \\ ${ }^{1}$ School of Medicine, Department of Public Health, University of Split, Croatia \\ ${ }^{2}$ Faculty of Maritime Studies, University of Split, Croatia
}

\begin{abstract}
Despite modern ship technologies, high-quality crew accommodation and exceptional communications, the absence of a doctor on board presents an issue in terms of the timely, adequate and efficient response to acute health disorders and life-threatening injuries.

A serious health condition of an injured or sick person, insufficient medical knowledge of the on-board officers, inadequately equipped ship's infirmary, or scarce supply of medicines are among the typical reasons for requesting professional shore-based medical assistance. This can be achieved by requesting Radio Medical Advice or by activating air-borne medical assistance, i.e. bringing a doctor by helicopter or by Medical Evacuation, i.e. transferring the ill or injured person to the shore medical institution. The Maritime Telemedical Assistance Services are available across the world. They use all the technical possibilities available, including e-mails and very widely used photo and video attachments as well as the emergency real-time live videos. In on-board practice, the most common solution is to use medical advice over the radio (through terrestrial or satellite networks). This paper discusses the ways of requesting professional medical advice or aid on board ocean-going merchant ships in the Republic of Croatia.
\end{abstract}

(Int Marit Health 2019; 70, 1: 42-46)

Key words: radio-medical advice, medical evacuation, maritime transport

\section{INTRODUCTION}

As a rule, merchant vessels do not carry a doctor as a crew member, with the exception of passenger and cruise ships. In compliance with the international and national regulations, all merchant vessels are equipped with the medicines specified in the mandatory lists and a ship's infirmary that consists of an adequate room and equipment $[1,2]$. All ships subject to the regulations established by the International Maritime Organisation (IMO) and the International Labour Organisation (ILO) must have adequate medical supplies that are periodically inspected, kept in good condition, and are ready for use whenever required. The quantities needed on board will depend on the duration and destination of the voyage, the crew size and the nature of cargo. The list assumes that on-board medical treatment is dispensed by an officer acting under the supervision and responsibility of the master. Ships with a doctor on board may carry an expanded range of medicines and other medical equipment and supplies [2, 3]. According to the legislation in effect in the Republic of Croatia, at least one on-board doctor is required on all passenger vessels in navigating category 1 (unlimited navigation) and in navigating category 2 (great coastal navigation) but the requirement also applies to vessels engaged in international voyage longer than 3 days and carrying 100 or more crew members or professional assistants, e.g. cooks, catering and entertainment staff, and the like $[4,5]$.

A serious health condition of an injured or sick person, insufficient medical knowledge of the on-board officers, inadequately equipped ship's infirmary, or scarce supply of medicines are among the typical reasons for requesting professional shore-based medical assistance. This can be achieved by requesting Radio Medical Advice or by activating air-borne medical assistance, i.e. bringing a doctor by helicopter or by Medical Evacuation, i.e. transferring the ill or injured person to the shore medical facility [6-8]. 
In maritime shipping, the request for professional medical aid on board represents the urgency call. In terms of emergency priorities, this type of message is just below the distress call. The medical urgency call may vary from medical advice to medical assistance including transfer. Medical assistance is available only within the range of the helicopter service, while the medical advice can be provided regardless of the ship's position. The request for medical aid can be performed through satellite radio-communication. These communications are considered to be safety or urgency communications and as such should have priority over routine traffic and will normally be free of charge to the mariner. They are established by dialling the urgency prefix and connecting with medical institutions by using special numerical codes. In the event of natural disasters such as volcano eruptions, the satellite connection/link may be unavailable due to ash particles in the atmosphere [9] and the only remaining option is to establish the radio communication with the shore. Vessels engaged in coastal navigation may lack satellite communication equipment and will use terrestrial radio communication and radio stations to contact the shore-based medical facilities [6-8].

The Maritime Telemedical Assistance Services are available across the world. They use all the technical possibilities available, including e-mails and very widely used photo and video attachments as well as the emergency real-time live videos. In on-board practice, the most common solution is to seek medical advice over the radio (through terrestrial or satellite networks).

\section{RADIO MEDICAL ADVICE}

The Radio Medical Advice, commonly called "Radiomedico", which is the prefix for this type of message, is a wide-spread maritime service for providing medical aid on board ships. The service is used to request assistance from various medical institutions or shore-based radio stations that have specialised in providing medical aid to vessels, including the doctor's assistance [7].

Today, there are over 300 radio stations providing medical advice worldwide. An updated list is available on board in the International Telecommunication Union publication List of Coast Stations and Special Service Stations which is published once in 2 years and updated with a supplement once in 6 months [7]. Many of these stations are integrated in large communication systems, including the best known:

- Automated Mutual Assistance Vessel Rescue - AMVER, New York;

- United States Navy Coast Guard;

- Medical Telecommunications Response Centre-MTRC, Maryland, USA;

- Medical Advisory System - MAS, Owings, USA;

- Rescue Coordination Centre - RCC;
- International Radio Medical Centre (Centro Internazionale Radio Medico [CIRM]), Rome, Italy.

The International Maritime Satellite Organisation (INMARSAT) was founded in London in 1982. By means of INMARSAT satellites, it is possible to dial the two-digit service code for requesting medical urgency calls free of charge. For example, code 32 is used for providing medical advice and code 38 for providing medical assistance via satellites through the Rescue Coordinating Centre (RCC) $[8,10]$. By dialling the service codes for medical aid, the satellite communication and the marine satellite Fleet77 terminal enable the seafarers to establish - within the range of the geo-stationary satellite signal $\left[76^{\circ} \mathrm{N}, 76^{\circ} \mathrm{S}\right]-$ the telephone connection via shore-based stations LES/CES (Land/Coast Earth Station) with the adequate hospital or medical emergency unit from any position at sea [8].

The CIRM is a specialised radio station seated in Rome, founded in 1920. It is one of the most frequently called radio stations in the world. Another internationally recognised radio station is the Medical Advisory System (MAS), whose headquarters is in Maryland, USA.

In the Republic of Croatia, medical advice can be provided by any of the three Coast Radio Stations (CRS): Dubrovnik Radio, Rijeka Radio or Split Radio, through VHF DSC Channel 70 , VHF Channel 16 or their respective operational channels. Free medical advice is also available through the radio communication (H.24) that is available 24/7. In the event of illness or injury, the CRS forwards the call to the on-duty doctor in the emergency service unit through the direct emergency telephone number 112 . In case of a marine accident that involves injuries, e.g. by the sailboat's mast, the call is first forwarded to the Rijeka-based National Maritime Rescue Coordination Centre (Nacionalna središnjica za traganje i spašavanje [MRCC]); then the MRCC coordinator contacts the appropriate medical service.

All vessels must be equipped with communication systems and their officers have to be qualified for providing medical aid. Radio Medical Advice is considered as the urgency call having the priority over any other messages, except for the distress call. Establishing and maintaining the connection with the Radio Medical Advice service can be carried out through the radio, satellite telephone, telefax, telex, or - exceptionally in modern era - radio-telegraphy.

Regardless of the mode of communication, the request for professional medical aid should be well prepared; otherwise the advice may be inefficient or harmful to the ill or injured person. As a rule, the communication with the doctor is performed in English language. At some points of conversation, it is acceptable to communicate in other international languages. The use of mother language is always the best, if this is possible in a particular situation. It is possible to seek advice from a doctor from other vessels: 
doctor is a mandatory crew member on board international passenger vessels and cruise ships [4].

The communication can be performed directly or by means of the appropriate signal codes [10] but it is best to communicate directly as this is the most efficient way. It is essential to provide the doctor with concise and clear information regarding the patient, and to understand and record the doctor's advice and instructions. When the communication is carried out through the radio telephone, it is recommended to record the doctor's response so that it could be repeated and interpret correctly. Communication interference may often occur. It slows down the response and the advice seeker should be persistent in order to get complete information on treating the ill or injured person.

It often occurs that the doctor providing medical advice is not familiar with the medicines and medical material available at the ship's infirmary, and a list of available drugs should always be at hand during the communication. The list of medicines (medicine chest and medical equipment) is defined by the category of navigation and complies with the requirements in the current edition of the International Medical Guide for Ships issued by the World Health Organisation (WHO). For instance, category A applies for ocean-going merchant ships. The items and their quantities in the medicine chest may vary with the ship's flag, but the required list of medicines and medical supplies should be carried on board and be regularly updated. For each item, the list should include details such as expiry date, storage conditions, and quantities remaining after purchase or use. A record of treatment given to any person on board, including the type and quantity of any medicines administered, must be entered in the ship's log. In some countries, it is compulsory to keep such a record. In addition, the master of the vessel is required to maintain a register of controlled drugs and this register must not be discarded before two years have elapsed after the date of the last entry [2].

The request for Radio Medical Advice is sent to the shore-based services through VHF, MF or HF channels with the appropriate Digital Selective Call (DSC). When the priority of the message is defined as urgent, the message contains the PAN-PAN call in radio-telegraph and radio-telephone communication, followed by the term "MEDICO" [8]. In order to avoid missing any important information during the Radio Medical Advice communication, the marine officer uses a prescribed standardised form that has to be filled in before seeking medical advice [2]. The form consists of separate sections for illness and injury, and makes an integral part of the International Medical Guide for Ships. The publications International Code of Signals features Chapter 3: Medical marks, with medical codes and numerical atlas of the human body. The use of codes allows avoiding errors in communication between the two parties, in particular when translating and interpreting special medical terminology. For example, the symptom referring to a "patient not having pupils of the same size" has the code MKX [10].

The information about a seafarer's injury or illness should be recorded on standardised forms to ensure that all important medical details are provided to medical care providers, whether on board or shore-based, or to officials such as coroners and the police. This information may also be of interest to others, including insurers, legal representatives, or ship owners. However interested these parties may be, they do not have a right to access any medical information about the patient. These forms, therefore, should not be used to communicate with anyone not concerned with the medical care of the crew member [2]. Owing to the modern technology, the carefully filled in form can be sent to the doctor by telefax or email.

Tables 1 and 2 describe the procedures for requesting medical aid through the terrestrial and satellite systems from the ships to the land-based medical services in the Republic of Croatia.

Terrestrial connections use VHF waves having a limited range of up to 30 nautical miles, but are reliable and in use at sea for all sorts of communication. In case a larger range is needed, MF or HF waves are used. These systems feature predefined frequencies for operation in the event of medical urgency, as described in the second column. The connection is carried out in a semi-duplex way, which implies that it does not allow both of the correspondents to talk simultaneously, but alternately. One of them talks while the other listens until the first correspondent says "over". Then the roles change.

The procedure for medical urgency is described in the second column. During the satellite communication we use the satellite telephone which functions like an ordinary full-duplex telephone. This means that, in case of poor understanding or forgetting details, a correspondent can repeat the question or the information at any moment.

\section{CONCLUSIONS}

Despite modern marine technologies, high-quality crew accommodation and exceptional ship communications, the absence of a doctor on board most merchant vessels presents an issue in terms of the timely, adequate and efficient response to acute health disorders and life-threatening injuries. Therefore it is essential to educate and train the seafarers in providing medical first aid and medical assistance, and seeking professional medical support. As part of the International Convention for the Safety of Life at Sea requirements, merchant ocean-going vessels are fitted with terrestrial and satellite communication systems. Satellite connection/link is available regardless of the area of navigation and is easily activated by using special prefixes for 
Table 1. Emergency procedures in terrestrial systems

\begin{tabular}{|c|c|c|}
\hline Distress call & Urgency call & Safety call \\
\hline $\begin{array}{l}\text { It is transmitted only if the vessel or its crew is in } \\
\text { immediate danger and an urgent assistance is } \\
\text { required by the master or skipper. }\end{array}$ & $\begin{array}{l}\text { It is transmitted if the distress call is not justified } \\
\text { (human life is not at threat), but the call refers to } \\
\text { safety of the vessel or its crew. The assistance is } \\
\text { explicitly required by the master or skipper. }\end{array}$ & $\begin{array}{l}\text { It is transmitted when an impor- } \\
\text { tant navigational or meteorolo- } \\
\text { gical warning should be given by } \\
\text { the master or skipper. }\end{array}$ \\
\hline $\begin{array}{l}\text { 1. Press the "distress" key on the appropriate } \\
\text { DSC VHF, MF or HF device. }\end{array}$ & $\begin{array}{l}\text { Sending the urgency message to all vessels and } \\
\text { shore radio stations, by using the menu on the } \\
\text { appropriate DSC VHF, MF or HF device. }\end{array}$ & Set the VHF radio on Channel 16. \\
\hline $\begin{array}{l}\text { 2. If we have time, the above message is prepared } \\
\text { and the nature of distress is defined (foundering, } \\
\text { collision, fire, grounding, listing...). }\end{array}$ & Set the VHF radio on Channel 16. & Set the VHF radio on Channel 16. \\
\hline 3. Set the VHF radio on Channel 16 and listen. & "PAN-PAN, PAN-PAN, PAN-PAN" & "SECURITE, SECURITE SECURITE" \\
\hline $\begin{array}{l}\text { 4. Only if a vessel or shore station has responded } \\
\text { and confirmed the message, the communications } \\
\text { resumes: }\end{array}$ & $\begin{array}{l}\text { All stations/name of the shore } \\
\text { station } \times 3 \\
\text { This is (name of the vessel) } \times 3 \\
\text { MMSI... } \times 3 \\
\text { Position is not necessary here. }\end{array}$ & $\begin{array}{l}\text { All stations } / \text { name of the shore } \\
\text { station } \times 3 \\
\text { This is (name of the vessel) } \times 3 \\
\text { MMSI... } \times 3 \\
\text { Position is not necessary here. }\end{array}$ \\
\hline $\begin{array}{l}\text { 5. MAYDAY } \\
\text { This is MMSI. } \\
\text { Details of the message include the number of crew } \\
\text { members/passengers, number of injured (if any). }\end{array}$ & Content of the message. & Content of the message. \\
\hline $\begin{array}{l}\text { 6. Type of assistance required and supporting } \\
\text { details. }\end{array}$ & $\begin{array}{l}\text { Define the type of assistance required } \\
\text { (emergency medical aid, medical advice...). }\end{array}$ & $\begin{array}{l}\text { State the details of the warning } \\
\text { (storm, obstacle to navigation...). }\end{array}$ \\
\hline 7. "Over" & "Over" & "Over" \\
\hline
\end{tabular}

Table 2. Emergency procedures in satellite systems

\begin{tabular}{|c|c|c|}
\hline Distress call & Urgency call & Safety call \\
\hline $\begin{array}{l}\text { It is transmitted only if the vessel or its crew is in } \\
\text { immediate danger and an urgent assistance is } \\
\text { required by the master or skipper. }\end{array}$ & $\begin{array}{l}\text { It is transmitted if the distress call is not justified } \\
\text { (human life is not at threat), but the call refers to } \\
\text { the safety of the vessel or its crew. The assistance } \\
\text { is explicitly required by the master or skipper. }\end{array}$ & $\begin{array}{l}\text { It is transmitted when an impor- } \\
\text { tant navigational or meteorolo- } \\
\text { gical warning should be given by } \\
\text { the master or skipper. }\end{array}$ \\
\hline $\begin{array}{l}\text { 1. Take the headphones and press the "distress" } \\
\text { key on the satellite terminal (Fleet77). }\end{array}$ & $\begin{array}{l}\text { Take the headphones and select Priority \#2 } \\
\text { on the satellite terminal (Fleet77). }\end{array}$ & $\begin{array}{l}\text { Take the headphones and select } \\
\text { Priority \#3 on the satellite termi- } \\
\text { nal (Fleet77). }\end{array}$ \\
\hline 2. MAYDAY $\times 3$ & "PAN-PAN, PAN-PAN, PAN-PAN" & "SECURITE, SECURITE SECURITE" \\
\hline $\begin{array}{l}\text { 3. Perform identification, state the vessel's call } \\
\text { sign, name and flag. }\end{array}$ & $\begin{array}{l}\text { This is (name of the vessel) } \\
\text { MMSI... }\end{array}$ & $\begin{array}{l}\text { This is (name of the vessel) } \\
\text { MMSI... }\end{array}$ \\
\hline $\begin{array}{l}\text { 4. State the nature of distress (foundering, colli- } \\
\text { sion, fire, grounding, listing...). }\end{array}$ & Position is not necessary here. & Position is not necessary here. \\
\hline $\begin{array}{l}\text { 5. Details of the message include the number of crew } \\
\text { members/passengers, number of injured (if any). }\end{array}$ & Content of the message. & Content of the message. \\
\hline $\begin{array}{l}\text { 6. Type of assistance required and supporting } \\
\text { details. }\end{array}$ & $\begin{array}{l}\text { Define the type of assistance required } \\
\text { (emergency medical aid, medical advice...). }\end{array}$ & $\begin{array}{l}\text { State the details of the warning } \\
\text { (storm, obstacle to navigation...). }\end{array}$ \\
\hline 7. "Over" & "Over" & "Over" \\
\hline
\end{tabular}

medical urgency. Due to maritime perils and unpredictable conditions, such as technical problems or natural disasters, the satellite connection/link may fail and can be replaced by terrestrial connections/links. This paper describes the emer- gency procedures in terrestrial and satellite communication systems that enable seafarers to contact medical facilities in the event of health issues, injuries or life-threatening situations at sea in the Republic of Croatia. 


\section{REFERENCES}

1. Regulation on Minimal Requests Regarding Medical Care on Ships, Boats and Yachts. In Croatian. National Gazette of Croatia. 2008; 14: 429.

2. International Medical Guide for Ships. Geneva: World Health Organization; 2007.

3. American College of Emergency. Health Guidelines for Cruise Ship Medical Facilities. Available at: . https://www.acep.org/patient-care/ policy-statements/health-care-guidelines-for-cruise-ship-medical-facilities/\#sm.0000tfhhkwwgqe3iqjl21xa4ucc2f (Accessed: $5 / 3 / 2019)$.

4. Ordinance on minimum safe manning on merchant marine ships of the Republic of Croatia. In Croatian. National Gazette of Croatia No. 63/07, 76/11, 46/13, 104/15, 31/16 and 83/16.

5. IMO Assembly Directive 1047 (27) Available at:. http://www.imo.org/ en/KnowledgeCentre/IndexofIMOResolutions/Documents/A\%20 -\%20Assembly/1047(27).pdf (Accessed: 22/01/2019).
6. IAMSAR Manual, International Aeronautical and Maritime Search and Rescue Manual, vol. II, ISBN 92-9194-925-6. IMO/ICAO, London/Quebec. 2007: 411.

7. List of Coast Stations and Special Service Stations. Available at: https://www.itu.int/en/ITU-R/terrestrial/mars/Documents/ List\%20IV_1st_Update_May2018.pdf (Accessed: 10/01/2019).

8. Manual for Use by the Maritime Mobile and Maritime Mobile-Satellite Services (Maritime Manual) ISBN: 978-92-61-17851-2. Geneva, International Telecommunication Union ITU. 2016;782.

9. Wilson T, Stewart C, Sword-Daniels V, et al. Volcanic ash impacts on critical infrastructure. Physics and Chemistry of the Earth, Parts A/B/C. 2012; 45-46: 5-23, doi: 10.1016/j. pce.2011.06.006.

10. International Code of Signals, as adopted by the Fourth Assembly of the Inter-Governmental Maritime Consultative Organization in 1965, US edition 1969, U.S. Government Printing Office, Maryland, revised 2003. 